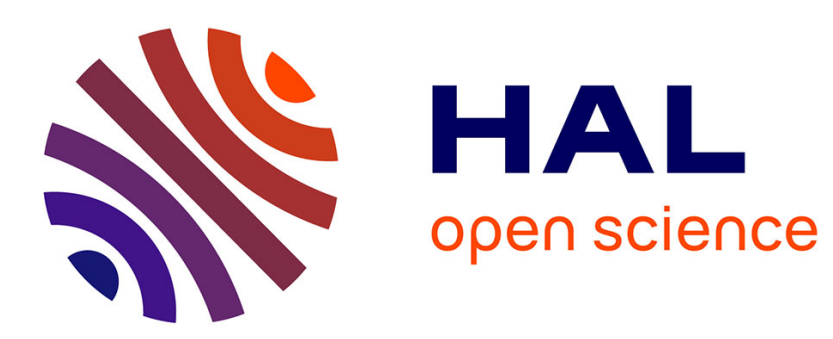

\title{
The Front National and the new politics of the rural in France
}

\author{
Gilles Ivaldi, Joël Gombin
}

\section{To cite this version:}

Gilles Ivaldi, Joël Gombin. The Front National and the new politics of the rural in France . Dirk Strijker; Gerrit Voerman; Ida J. Terluin. Rural protest groups and populist political parties, Wageningen Academic Publishers, 2015, 9789086862597. 10.3920/978-90-8686-807-0_11 . halshs-01245081

\section{HAL Id: halshs-01245081 https://shs.hal.science/halshs-01245081}

Submitted on 16 Dec 2015

HAL is a multi-disciplinary open access archive for the deposit and dissemination of scientific research documents, whether they are published or not. The documents may come from teaching and research institutions in France or abroad, or from public or private research centers.
L'archive ouverte pluridisciplinaire HAL, est destinée au dépôt et à la diffusion de documents scientifiques de niveau recherche, publiés ou non, émanant des établissements d'enseignement et de recherche français ou étrangers, des laboratoires publics ou privés. 


\title{
The Front National and the new politics of the rural in France
}

\author{
Gilles Ivaldi, URMIS-CNRS, University of Nice Sophia Antipolis, gilles.ivaldi@unice.fr \\ Joël Gombin, CURAPP, Université de Picardie Jules Verne, joel.gombin@u-picardie.fr
}

The French Front National (FN) epitomizes the post-industrial radical right party family in Europe, manifesting a predominantly urban cultural and economic malaise. The party has however progressively formulated a more comprehensive rural agenda over the years, idealizing agrarian values and specifically addressing farmers' interests. Since the early 2000s, the FN has grown stronger in rural areas. It has done so by challenging the status quo represented by the Common Agricultural Policy of the European Union and the traditional centerright and Gaullist alignment of the farming world. More recently, the party has embraced a more leftist economic agenda catering for intensifying demands for state intervention and public service provisions in rural territories. In 2012, the electoral success of the FN in peripheries reflected primarily the territorialization of the subjective and objective proletarianization of the working and lower middle class.

\section{Introduction}

In the first round of the 2012 French presidential election, the Front National (FN) won 17.9 per cent of vote. Marine Le Pen bested her father's score of 2002 when he made it through to the presidential second round run-off. Amid economic crisis, support for the FN increased among production and service workers and lower middle-class voters the most severely hit by unemployment and economic difficulties. Reflecting the softening of the party's profile, Marine Le Pen assembled support from social groups who were traditionally adverse to the FN such as women (Mayer 2013). Another notable feature of the electoral resuscitation of the FN in 2012 was its consolidation in rural areas. The radical right gained important footholds in the countryside and in the distant outskirts of the large cities, showing a move from original urban constituencies into rural France.

The 'ruralization' of the FN calls for further analysis however. Operationalizing the 'rural' space is not unequivocal. It often confronts the risk that the diversity of local situations be excessively homogenized. The rural coalition by the radical right should not occlude the consideration that a variety of segmented socio-economic interests and divergent political cultures coexist in the rural world in France today. Important reconfigurations have occurred in both the agricultural sector and the demography of rural areas over the past decades, which call for a contextualization of the FN vote.

This chapter examines the relationships between the Front National and the rural, as regards the policy positions taken by the party, but also in terms of the dynamics behind the electoral support for the radical right in France's countryside. The first section examines the FN's extreme right origins as a mostly urban phenomenon with little roots in earlier movements of rural protest. We argue that the party has also failed to establish links with actors currently representing the interests of the rural world. We then turn to looking at how the FN has progressively built up a more comprehensive rural agenda embedded in changes in the party's competitive positions. We focus on the recent Keynesian shift by the FN. Endorsing a new statist redistributive economic agenda was the party's response to the intensifying demand for social welfare and public service provisions in rural areas.

The second section examines the demand-side of the ruralization of the FN. Two important facets are discussed. The first concerns the increase in farmer support for the radical right. Farmers have become over-represented in the FN's electoral base since the early 2000s. Moreover, this support has a specific geography, revealing a challenge to the traditional center-right and Gaullist alignment of the farming world in France. A second aspect concerns the 'peripheralization' of the FN vote and the 
growth in support for the radical right in periurban areas - referring to outer satellite towns more distant from the large cities. The spatial distribution of the FN vote along the 'urban gradient' corroborates the geography of social and economic inequality. Territorial divisions based on socioeconomic positions reflect both the subjective and objective proletarianization of the working class and the lower middle class.

\section{Origins and party ideology}

The historical roots of the Front National lay in the post-war French extreme right. The FN was formed in 1972 from a disparate coalition of ultra-nationalist groups, nostalgics of the Vichy regime and former supporters of French colonial Algeria. The party was electorally irrelevant during the 1970s. It made its first national breakthrough in the 1984 European elections, running on a strong nationalist populist platform fostering xenophobia and anti-Semitism.

*** Table 1 here ***

Since its political take off, the FN has become a permanent feature of the French party system, both nationally and locally (see Table 1 below). The party has established a distinctive appeal among French voters by politicizing immigration and criminality issues. It advocates strong anti-immigrant and welfare-chauvinist policies coupled with a hard stance on law-and-order and a fierce rejection of the European Union. In 2011, Marine Le Pen took over party leadership after nearly four decades of unlimited rule by her father. She has modernized the party's strategies and programme to rebrand the old FN and present it in a more affable style. However, the FN has retained most of its core authoritarian, nativist and protectionist policies (Ivaldi 2012).

\section{A prototype of the New Radical Right}

Most scholars agree on the localization of the Front National on the extreme right margin of French politics. For many years, the French FN has epitomized the prototype of the modern radical right party family in Europe. It has been primarily considered the political manifestation of the cultural and economic malaise caused by immigration, structural unemployment and criminality in industrialized urban areas. In the early stage, the FN was regarded as a prototypical case of Kitschelt's new radical right (1995: 91) mixing free market economics and culturally particularistic authoritarian appeals. According to Ignazi (2003), the French FN epitomizes a third wave of post-industrial extreme right parties manifesting a reaction against the process of cultural liberalization. Betz (1994:108) sees in the $\mathrm{FN}$ a variant of national-populism mixing ethno-pluralist policies with an economically protectionist agenda. Finally, Mudde (2007: 41) regards the French FN as representing the successful party family of the populist radical right whose key ideological features are nativism, authoritarianism and populism.

The main features of the FN differ from agrarian populism. According to Canovan (1981), agrarian populism is a reaction against modernization recognizable on the basis of the distinct composition of its support base which primarily consists of farmers and/or peasants (p.8). More generally, agrarian parties are distinguished by their origins and their defense of the rural periphery by mobilizing within the peasantry in opposition to the national urban establishment. In contrast to other European versions of populism such as the True Finns in Finland or Self-Defence in Poland for instance, which 
have their roots in agrarian movements, the French Front National finds no historical legacy in the rural world. ${ }^{1}$

The Front National emerged and consolidated as a predominantly urban phenomenon. Its politicization of immigration and law-and-order issues concerned urban and sub-urban constituencies. This comes in sharp relief with the rural component that was found in earlier manifestations of right-wing populism in France, most notably the Poujadist rebellion in the mid1950s (Goguel 1981: chap.7). ${ }^{2}$ The Union for the Defense of Shopkeepers and Craftsmen (Union de Défense des Commerçants et Artisans, UDCA) was created by Pierre Poujade in 1953 as a right-wing movement of anti-tax revolt in reaction to France's economic modernization and rapid industrialization. In the 1956 legislative elections, the Poujadist lists won 11.6 per cent of the vote and 51 seats. The UDCA assembled primarily a petty-bourgeois constituency catalyzing small-town rural shopkeepers and small farmers. They coalesced against big corporate businesses, large commercial surfaces, left-wing trade unions and 'corrupt politicians'. The Poujadist map was different from that of the Front National: in 1956, the Poujadist vote was concentrated in the rural departments of Western France (Maine-et-Loire, Charente-Maritime, Indre-et-Loire, Deux-Sèvres, Aveyron, Gers) and the South, from Tarn-et-Garonne to Vaucluse. In contrast, during the 1980s, the support for the $\mathrm{FN}$ originated primarily in the industrialized and urban regions of the country, east of the Le Havre-Valence-Perpignan line (Perrineau 1998).

Historically, agricultural protest and farmers' upset have been channeled by other political forces than the FN in the political arena. The FN has never established formal relationships with farmers' interest groups or rural protest movements. In the 1990s, the party strived to form a number of flanking organizations. The latter aimed to expand its sectoral appeal to specifically targeted professional groups. In rural areas, this strategy was embodied by founding the National Association Hunting Fishing Environment (Cercle National Chasse Pêche Environnement, CNCPE) and the National Association of French Farmers (Cercle National des Agriculteurs de France, CNAF), but these were mostly empty shells.

French farmers have traditionally been represented by parties of the conservative rather than radical Right. ${ }^{3}$ This was due to strong links between farmers' professional unions with high rates of membership, and the Gaullists (Rémy 1972). Rural Catholicism has also been a strong deterrent to the FN vote among farmers (Mayer 1995). Hervieu and Purseigle (2013) show that political preferences and attitudes among farmers continue to have a strong rightist orientation. Religious and moral beliefs are predominant among farmers. They adhere also to core right-wing values, in particular the ethics of 'hard work' while strongly opposing 'assistanat' (welfare scroungers).

Farmers' interests have become however more politically fragmented over time. Socio-economic segmentation and regional differentiation have also increased in the 'rural worlds' (Gombin and Mayance 2010). On the left, grassroots mobilization in the Peasants' Confederation (Confédération Paysanne, CP) took the center stage of the populist rural agenda in the late 1990s through direct

\footnotetext{
${ }^{1}$ Agrarian elements were found in the French extreme right during the interwar period. The most prominent organization was the Green Shirts, founded by Henry Dorgerès (Ory 1975 ; Paxton 1997).

${ }^{2}$ Despite Le Pen's participation in the Poujade movement and the assimilation by the FN of the UDCA's legacy of fiscal populism.

${ }^{3}$ There has been nevertheless a tradition of 'rural communism' in Dordogne (Boswell 1998). Zones of rural support for the French Communist Party (Parti Communiste Français, PCF) were found in the northern and western edges of the Massif Central, and along the Western Mediterranean coast (see also Mischi and Streith 2004).
} 
action against globalization, Americanization and the agro-business. The Confederation was led by José Bové, a longtime activist who began his political career in the anti-military, farmer and environmental protest movements of the 1970s. Actions by the Confédération Paysanne included the dismantling of McDonalds restaurants or, years later, the launching of anti-GMO campaigns through the ripping up of genetically modified crops in Southern France. While the FN has shown convergence with the critique of economic globalization and the World Trade Organization (WTO) in the ideas of the Confederation, the two organizations are strongly antagonistic. The Confédération paysanne's 'altermondialist' positions are deeply entrenched in the internationalist anti-globalization movement. The latter has historically fostered links with both the ecologist and the anti-liberal sectors of the French left while strongly rejecting the $\mathrm{FN}^{4}$

On the right, the rural urban cleavage underpinned the formation of Hunting, Fishing, Nature, Traditions (Chasse, Pêche, Nature, Traditions, CNPT). This organization grew from a small single-issue shooters' rights group in the 1980s to a more distinctly agrarian party in the early 2000s. In the early stage, CPNT contested European regulations on hunting and opposed pro-environment laws seen as antagonistic to the collective interests of farmers. The party won its first votes in the 1989 European and 1992 regional elections. It then achieved its best performance in the 1999 European ballot where it totaled 6.8 per cent of the national vote cast and won six seats. In 2002, CPNT's leader Jean SaintJosse ran a successful presidential bid receiving 4.2 per cent of the presidential vote. His conservative Eurosceptic and agrarian agenda incorporated a broader set of rural issues. These included tax incentives for farmers, the fight against 'desertification' (rural flight) and the need to sustain public provision of services in rural France. The party's strongholds were found in rural areas such as Somme, Manche or the Aquitaine region (Bussi 2003).

In 2007, CPNT's presidential candidate, Frédéric Nihous, polled a mere 1.2 per cent of the vote. Whilst the FN received support from former CPNT voters across a number of regions in $2012,{ }^{5}$ the two parties remained independent from one another both organizationally and strategically. Following Nihous' electoral setback in 2007, CPNT travelled a centripetal trajectory. The party merged into the mainstream Union for a Popular Movement (Union pour un Mouvement Populaire, UMP) in 2012 after a short-lived attempt to build a coalition with right-wing Eurosceptics of the Movement for France (Mouvement pour la France, MPF) under the Libertas banner in the 2009 European elections. ${ }^{6}$

Finally the FN has been continuously excluded from collaborating with the main farmers unions, namely the dominant National Federation of Farmers' Unions (Fédération Nationale des Syndicats d'Exploitants Agricoles, FNSEA), the Rural Coordination (Coordination Rurale, CR) and the aforementioned Peasants' Confederation. The FN has shown hostility in particular towards the more mainstream FNSEA, accusing the latter of representing the interests of the big agro-businesses against small tenant farmers. In the 2012 presidential campaign, Marine Le Pen received criticism from the FNSEA on her strong opposition to Europe and claim to dismantle the European Common

\footnotetext{
${ }^{4}$ In the 2005 referendum, Bové campaigned together with the Communists and a number of anti-globalization groups against the European Constitution. He then ran independently in the 2007 presidential election where he competed with both the PCF and the far left over the anti-liberal electorate. More recently, the Confédération paysanne has moved closer to the Greens' Europe Ecologie (EE) coalition.
}

${ }^{5}$ There was empirical evidence of regionalized vote transfers between 2007 and 2012. A significantly positive cantonal correlation was found between the 2007 Nihous vote and the 2012 Le Pen vote in Picardie, Nord-Pasde-Calais, Aquitaine, Auvergne and Haute-Normandie.

${ }^{6}$ Locally, former cadres of CPNT such as Nathalie Huiart in the department of Somme joined the FN through the newly formed Rassemblement Bleu Marine (RBM) in 2012. 
Agricultural Policy (CAP). Ten years earlier, the FNSEA had publicly supported Jacques Chirac against Jean-Marie Le Pen in the second round run-off of the 2002 presidential election.

The accentuation in the FN's protectionist and Eurosceptic agenda has certainly led to greater ideological proximity with the strong anti-CAP positions taken by the predominantly right-wing Rural Coordination. Yet formal political rapprochements with the FN have been restricted to individual trajectories. ${ }^{7}$ In 2012, the Coordination's president Bernard Lannes publicly refuted accusations of political collusion with the $\mathrm{FN}$ and reiterated his claim of independence from all political parties.

\section{Issues and policies: a new 'ruralist' strategy by the FN}

The FN has developed a more comprehensive rural agenda over the years. This is first demonstrated by the gradual increase in salience of agriculture and countryside-related issues in the party's election platforms since the mid-1980s. Figure 1 shows that rural-based policy statements concerning agriculture and farming have been given more importance by the FN over time, while there has been a decline in emphasis by parties of the mainstream Right. A change in relative salience occurred in the mid-1990s, whereby the FN took the lead on agricultural issues in the party subsystem of the Right. As will be discussed, this shift in emphasis exemplifies some of the tactical 'catch-allist' choices made by the party as a means to expand its electoral appeal beyond its early urban strongholds.

*** Figure 1 here ${ }^{* * *}$

As early as 1973, the FN pledged to fight rural flight and the impoverishment of farmers. The party argued that it would defend the interests of French farmers against foreign land owners and investment banks, and that it would reinstate higher prices for farming commodities. In the 1980s, agriculture and farming concerns were incorporated into the new national-conservative agenda of the FN. The party embraced the paternalist and rural traditionalist ideology characteristic of French right-wing nationalism. The 'hard-working' farmers were thus romanticized and the peasantry was idealized as the typical holder of national identity and entrenchment. According to the 1984 party platform, "the cultivator doesn't treat his land with despise unlike the nomad who leaves a field as soon as his flock has grazed it into a no-man's land" (p.34).

The celebration of traditional agrarian virtues became ubiquitous to the FN's appeal. The 1986 program referred to "France as the land of our fathers, the land that they have cleared and defended for centuries; the country that they have shaped in its landscapes (...) and that they have fertilized with their sweat and their blood" (p.29). In 2012, Marine Le Pen did not deviate from the lyric evocation of farmers: "the French soul is intrinsically peasant", she stressed during the presidential campaign. "Our countryside is immensely rich, and this is where the best of France's civilization is perpetuated". 8

Changes have occurred however in the FN's treatment of farming and rural issues over time, reflecting more generally the party's economic policy trajectory. During the $1980 \mathrm{~s}$, agriculture and rural concerns formed part of the capitalist appeal by the FN to bourgeois voters. This was illustrated

\footnotetext{
${ }^{7}$ Organizational contiguity was increased by the merging in 1994 of the CR with the former more FN-inclined Fédération Française de l'Agriculture (FFA). FFA president Alexis Arette had briefly joined the FN (Bihr 1998).

${ }^{8}$ Speech in Châteauroux, 26.02.2012 (http://www.frontnational.com/videos/discours-de-marine-le-pen-a-cha $\%$ CC\%8teauroux/)
} 
for instance by the invocation of the core values of "profit, property, economic inequality and honor" in the 1984 electoral manifesto (p.27). ${ }^{9}$ Anti-statist deregulation policies, support for small family businesses and the dissolution of the bureaucracy were pervasive to the 1986 platform. The FN would call for the "liberalization and de-socialization" of French farming, while advocating free enterprise, the suppression of quotas, tax incentives for small family businesses and cuts in the contributions paid by farmers to national social security.

Interestingly, the 1986 programme introduced a first set of protectionist measures against imported agriculture commodities, while stressing France's need for food self-sufficiency. This nationalistic tone heralded a more substantial policy shift during the mid-1990s. During that period, the FN toned down free market capitalism to espouse a more protectionist agenda. This move was consistent with the party's platform against EU federalism and the loss of national sovereignty. The 1993 manifesto brought new social and anti-globalization policy features into the party. With regards to farming in particular, the FN's programmatic priorities included measures rejecting the GATT (General Agreement on Tariffs and Trade), the EU and the WTO. While keeping with tax incentives and the pledge to put an end to trade union monopoly in the agricultural sector, the FN advocated a mix of social policies. These included a specific allowance for young farmers, an increase in pensions as well as a debt moratorium for the defense of small family farms with a view to stopping rural flight.

In one sense, the FN's agricultural policies became more far reaching. This was perceptible in the 2002 presidential manifesto which claimed to represent the sectional interests of farmers against the threat of both the EU and economic globalization. Most strikingly, the FN claimed that France should leave the EU (p.70). The 2002 platform reiterated the party's positions against intensive farming, introducing anti-GMO policies and, in the specific context of the 'mad-cow' disease crisis, a call for more stringent sanitary safety measures. Reflecting on the emergence of new rural questions, the 2002 manifesto tapped into the issue of 'rurality' (ruralité) and reaffirmed the imperative to "combat the desertification (rural flight) of rural areas" (p.49). It maintained nevertheless a clear right-wing stance revolving around additional tax incentives and the creation of special economic zones in rural municipalities.

Attention for agriculture and rural issues peaked in the 2012 elections. The FN displayed a significant policy shift towards the left on the economic dimension (Ivaldi 2013). The party embraced interventionist and protectionist policies breaking further away from its capitalist preferences of the 1980s. Framed as a new set of social and economic issues, 'rurality' re-emerged in the presidential manifesto. The party pushed an agenda of public service provision and higher government spending and health services in rural areas. The 2012 presidential platform claimed that "public services should be available to everyone, everywhere" (p.9) and pledged that the FN would "develop public provisions for public services of proximity (...) to combat the desertification of rural areas" (p.13). ${ }^{10}$ In Châteauroux, Marine Le Pen called similarly for "the French constitution to guarantee equal access to public services regardless of income or place of residence" (Speech in Châteauroux, 26.02.2012).

This conflated with an accentuation in the party's Eurosceptic and protectionist stands. In 2010 the FN called for France to leave the Euro. During the 2012 elections, the party advocated the renegotiation of both the "shameful EU directives" and the "treaties that hurt France" in order to "eliminate free competition rules applicable to specific sectors such as transport or postal services". According to the FN, postal services should be renationalized and price controls should be established

\footnotetext{
${ }^{9}$ In 1984, no specific farming policies were formulated by the FN however.

${ }^{10}$ There were already signs of this policy shift in the 2007 election. The 2007 manifesto already included a pledge to increase government spending to expand public services (hospitals, crèches, retirement homes) in rural areas (p.27).
} 
over basic commodities such as food, gasoline or energy. France should also leave the Common Agricultural Policy to implement a national system of agricultural subsidies - in the form of a new French Agricultural Policy (FAP). Measures should be taken to protect small farmers from larger agribusinesses, while a 'buy French act' would give priority to agricultural commodities produced in France.

Thus, in recent years, the endorsement by the FN of a neo-ruralist agenda has certainly extended further what Kitschelt (1995) originally described as the party's 'catch-all' extremism (p.95). In 2012, Marine Le Pen appealed to the habitual petty-bourgeois and working class clienteles of the populist radical right. She also tried and identified her party with a larger coalition, which she repeatedly referred to as the 'invisible constituency'. The latter included "workers, farmers, students, pensioners, shopkeepers, civil servants and employees". Their common interests would be threatened by 'the powerful' representing the dominant 'globalist' (mondialiste) ideology i.e. national politicians, the European Commission, financial markets, CAC 40 companies, the 'super wealthy', 'loutish businessmen' or large retail companies".

Marine Le Pen has revisited the FN's traditional populist 'heartland' through redrawing the contours of the opposition that populism classically establishes between the 'pure people' and the 'corrupt elite' (Mudde 2007:23). In the context of economic crisis, these categories were constructed along socio-economic rather than strictly political or cultural lines - e.g. the hard-working 'little people' against big corporations, the neo-liberal EU and the global markets -, ignoring however the objective divisions that exist among the so-called 'invisible constituency'. In 2012, this populism of the 'little man' helped the FN broaden its appeal to the lower sectors of the middle-class hit by the economic recession. The party reached out to the "forgotten rural France" pledging that it would tackle social segregation, high levels of unemployment and growing feelings of insecurity, both cultural and economic. ${ }^{11}$

\section{The making of a new 'rural' constituency}

Analyzing a party's relationship to society requires that we look not only at its programmatic supply, but also at the demand side. In this section, we examine the relationship of the Front National to the rural and agricultural worlds by looking at its electoral socio-demographic make-up and geography, and their transformation over time. ${ }^{12}$

\section{Farmers and the French radical right}

Since the late 1980s, the FN has been characterized by its cross-sectional appeal in the French electorate, showing an over-representation of petty-bourgeois and working-class voters (Mayer 2002). Because the overall share of farmers in the population is very small and declining, ${ }^{13}$ poll estimates of votes in the agricultural sector must be taken with care. However, available survey data

\footnotetext{
${ }^{11}$ The FN's ruralist policies overlapped with its traditional law-and-order agenda, as it called for an increase in 7 police forces (gendarmerie) in rural areas.

${ }^{12}$ One problem is that FN voters tend to conceal their vote and are therefore continuously under-represented in national polls.

${ }^{13}$ In the last fifty years, the farming population has declined from about a third down to less than 4 per cent. In 2010, farmers accounted for 3.4 per of the French population (see Ministère de l'Alimentation, de l'Agriculture et de la Pêche, Centre d'études et de prospective, Analyse, "Les agriculteurs dans la société », 14 April 2010).
} 
seem to indicate that farmers were continuously under-represented in the FN's electorate up to the late 1990s, while turning more massively to the radical right after 1997.

Farmers were less inclined to support the radical right during the 1980s and the 1990s. In 1984, an estimated 8 per cent of farmers voted for the FN in the European election where the party made its first national breakthrough with 11 per cent. ${ }^{14}$ The electoral geography of the FN remained mostly industrial and urban (Perrineau 1998). In the 1986 legislative elections, the FN polled about 7 per cent of the farmer vote, less than its national score. According to Boy and Mayer (1997), 7 per cent of the farmers voted for Jean-Marie Le Pen in the 1988 presidential - twice less than the rest of the population-,demonstrating their continuing resistance to the radical right. ${ }^{15}$ Another clue that the 1988 support for Jean-Marie Le Pen was rather low among farmers and, more generally in the rural world, is provided by Boussard and Chiche (1992). The results of their ecological analysis show that the FN vote was lower in the 104 constituencies (circonscriptions) where the share of farmers was the highest in 1988, compared with the other 473 constituencies. Their study demonstrates also that constituencies with a higher proportion of farmers had the lowest share of the FN vote in the 1989 European elections.

While its sociology changed dramatically between 1988 and 1995, showing in particular a proletarianization of its support (Mayer and Perrineau 1996; Perrineau 1995; Mayer 2002), the audience of the $\mathrm{FN}$ among farmers and more generally rural voters remained more or less stable. In the 1993 legislatives, the FN candidates won 10 per cent of the farmer vote compared with 12.4 per cent nationally (Mayer 2002). In 1995, 8 per cent of farmers (and $0 \%$ of farm workers - sic) supported Jean-Marie Le Pen's presidential bid (Boy and Mayer 1997), a proportion estimated at about 10 per cent in Mayer (2007). According to Mayer (2002) the farmers' FN vote dropped down to a mere 2 per cent in the 1997 legislative elections - a figure which should be taken with caution however due to possible methodological bias.

The FN's breakthrough among farmers and rural voters occurred between 1997 and 2002. The evidence from cross-sectional surveys is corroborated by growing electoral returns in rural areas during the same period. Le Pen won his first notable success in the rural and agricultural worlds in the 2002 presidential election. On that occasion, the FN leader received levels of farmer support similar to those in its core petty-bourgeois - businessmen and shopkeepers - and working-class constituencies, and among white-collar voters (Cautrès and Mayer 2004). Mayer (2007) suggests that Le Pen might have received as much as 22 per cent of the farmer vote in the first round of the 2002 presidential election, giving him a decisive thrust to progress to the second round runoff. This first success was even more remarkable that the FN confronted direct competition from the ruralist CPNT candidate in rural areas.

While the core of radical right support remained with the urban working class, the FN grew considerably stronger among rural voters, far beyond farmers, in the early 2000 s. Moreover, the support for the party declined simultaneously in urban areas. Let us recall here that the rural-urban division lost salience in France after the Second World War, mostly because of large scale urbanization. France mutated from a predominantly agricultural and rural to a largely urban industrial society during the Trente Glorieuses (1945-1970). Lévy (2003) argues however that the 2002 presidential election was a turning point in French politics: the cleavage between urban centers and their rural periphery produced stronger effects than ever before in the Fifth Republic.

\footnotetext{
${ }^{14}$ For 1984 and 1986, we use pooled datasets of cross-sectional surveys conducted by the French polling institute BVA after the European and legislative elections.

${ }^{15}$ The same figure appears in Mayer (1992). The author argues that the vote for the FN leader was stronger among farmers most integrated into the farming milieu - which seems a bit counterintuitive.
} 
In 2007, Jean-Marie Le Pen's last presidential bid marked a critical electoral setback for the FN with 10.4 per cent of the vote. This reversal reflected important swings by FN voters to the UMP candidate Nicolas Sarkozy. The latter had embraced a strong authoritarian stance coupled with an agenda of stricter immigration control. Rural and farming voters showed however a significantly higher degree of loyalty to the FN's leader (Fourquet 2008). Gombin and Mayance (2010) suggest that farmers were still more likely than other occupational groups to support the FN. Based on an ecological analysis of registered voters, they calculate that about 12 per cent of registered farmers voted for Le Pen in 2007 - yielding an estimated 13.5 per cent of the valid vote cast, compared with a 10.4 per cent national average.

The FN made an impressive electoral comeback in the 2012 presidential election, winning 17.9 per cent of the first-round vote. As will be discussed below, this electoral resuscitation was largely attributed to the growth in support for the FN in peripheral rural territories. The party maintained also its attractiveness to voters in the agricultural sector: the 2012 French election study showed that 21 per cent of farmers voted for the radical right's candidate. ${ }^{16}$ Based on ecological data, it can be estimated that 19 per cent of registered farmers voted for Marine Le Pen - compared with 14.5 per cent in other registered voters -, representing 21.8 and 17.8 per cent of the valid vote cast, respectively.

Overall, then, the FN's support among farmers - and more generally among rural voters - was very low in the early years, but it then grew more rapidly than average and today it is higher than in the rest of the electorate. This evolution is summarized in Figure 2 which displays the results from a multilevel growth model using aggregate election returns (Gombin 2013b). This longitudinal approach allows to assess the evolution of FN support among farmers over time. As can be seen, the FN vote grew more rapidly in the cantons where farmers represent a larger share of the population. For instance, in 2012, Marine Le Pen won a 13 point surplus in cantons where shares of farmers were 20 points above the national average. Moreover, this evolution has been largely independent from the party's performances among petty-bourgeois voters - craftsmen and shopkeepers. Among the latter, there was a marked decline in the propensity to support the radical right between 1995 and 2012, which was the almost exact inverse of the trend observed among farmers.

*** Figure 2 here ${ }^{* * *}$

However, farmer support for the radical right is not uniform across the country. It has a very specific geography, which is different also from the more general political geography of the FN. This is illustrated in Figure 3 which shows an estimation of the $2012 \mathrm{FN}$ vote among farmers across the country. Departments with the highest level of farmer support for the FN were located in the greater Paris area as well as in the Northern and Western regions - from the Nord to the Landes, including Normandy, Brittany and the interior Western part of the country. Strongholds of FN's farmer vote were also found in Bouches-du-Rhône, Isère and Haute-Savoie.

*** Figure 3 here ${ }^{* * *}$

These areas are characterized by rather large scale and intensive farming. They are also those in which farmers were the most likely to vote for Sarkozy and the UMP in $2012(R=0.48)$. These regions have experienced economic difficulties, as have for instance milk producers, and have been among

\footnotetext{
${ }^{16}$ Source: French Election Study 2012 (TNS-SOFRES / CEE Sciences-Po Paris).
} 
the most severely affected by the crisis in the agricultural sector. The CAP has historically proven an effective shield for farmers, helping them secure their income while national agricultural markets were opened to greater international competition. Consequently, the French farming world has proven one of the strongest supports for the European integration process. However, over the last years, this protective effect may have become less effective for specific subgroups of farmers, crystallizing discontent with the EU and fostering support for the FN's national-protectionist policies.

The FN's electoral growth among farmers reflects therefore the weakening of the links which originated in the pact forged between the agricultural sector and the Gaullist state in the late 1960s. This pact was well represented for instance by the Pisani plan - an ambitious state-driven plan to help French agriculture modernize and become more competitive - and the creation of the CAP in the early 1960s. In contrast, smaller farm tenants in the South were more distant from this original arrangement and continued to vote more solidly for parties of the Left. In this, the development of the FN vote among farmers represents both an alternative and a challenge to the traditional centerright and Gaullist alignment of the farming world in France. It is also consistent with the conservative worldview which continues to dominate political attitudes and values among farmers (Hervieu and Purseigle 2013: 225).

\section{The peripheralization of support for the radical right}

The growth in farmer support for the radical right has been accompanied by a 'peripheralization' of the FN vote. This phenomenon has been extensively documented by scholars in France (Lévy 2003 \& 2007, Bussi et al. 2011, Rivière 2009, Fourquet 2012, Girard 2013). Originally an urban phenomenon, the geography of the FN gradually shifted away from cities while support for the party augmented in the more remote urban peripheries. This process of 'peripheralization' is illustrated in Figure 4 below, which displays the variation in support for the FN since 1995 according to the type of municipality. It shows in particular that the gap between larger urban cores and their more remote private suburban housing peripheries has grown larger over time. In 2012, the FN vote was thus significantly stronger in rural communes than in the more urbanized areas. More importantly, electoral support for the radical right peaked in periurban towns and subareas in a situation of 'multicentricity' i.e. adjacent to multiple centers of economic activity and employment.

*** Figure 4 here $* * *$

A number of explanations have been put forward to account for this evolution. Based on a theory of 'social relegation', some authors see this evolution as the result of in-migrations and sociodemographic transformations. The metropolitanization process (Davezies 2008) in particular would push voters in low-income households further from urban centers, to the more distant outskirts of the metropolis, where they would feel socially excluded and subjected to 'cultural insecurity' (Guilluy 2010 \& 2011). Lévy (2013) argues on the other hand that the FN's over-representation in periurban areas could reflect residential choices by xenophobic voters deliberately moving out of urban zones to avoid direct contacts with immigrants. The study by Cartier et al. (2008) provides indeed empirical evidence suggesting that the evolution in the geography of the $\mathrm{FN}$ vote has been correlative of the spatial redistribution of social groups which make up the core constituencies of the radical right, which moved away from deprived social housing neighborhoods to more remote areas of individual private houses (Cartier et al. 2008). 
Many studies have pointed to the social and economic heterogeneity of periurban areas however (Chalard 2006; Rivière 2008; Girard 2013). Gombin and Rivière (2013) suggest for instance that other factors should be taken into account, in particular existing levels of economic inequality. As discussed above, understanding the growth in $\mathrm{FN}$ support in periurban areas requires also that we consider the 'supply-side' of the equation. We have already stressed how the FN recently tried to reach out to voters in the so-called 'invisible constituency' in urban peripheries and rural areas. The neo-rural repositioning of the $\mathrm{FN}$ testifies to the socio-economic reconfiguration of the rural space and the territorialization of class-based divisions. These have resulted in the politicization of new issues concerning in-migrations, models of rural development and the transformation of the rural-urban divide.

The territorial divide is nested in France's higher-order class cleavage. Overall, a relationship exists between the geography of economic inequality and changes that have occurred in the spatial distribution of FN support. Access to urban centers has become more difficult for larger segments of the population, particularly in the lower class locations. Access to urban peripheries has become equally competitive. This has resulted in growing conflicts among social groups which differ not only in terms of their socioeconomic status but also with regards to their relationship to the territory they live in and how they use it. Territorial divisions based on socio-economic positions reflect the proletarianization of the working class and the lower middle class (Gombin 2013a) and the perception of this process by those concerned -a process which mainstream parties have yet failed to address. Rather than revealing a new rural-urban divide, changes in the FN's geographical contrast manifests the geographical clustering of voters from the middle and lower class locations in semirural areas from which the FN is increasingly drawing electoral support. As suggested by Woods (2003:310), new waves of rural protest are found across developed countries, which illustrate a change from 'rural politics' to 'politics of the rural'. The latter mobilizes on the traditional array of farming issues, but also on issues concerning housing, transport and the preservation of rural services.

\section{Conclusion}

Whilst clearly rooted in urban post-industrial society, the FN has nevertheless embraced the classic agrarian and paternalist values of French right-wing nationalism. The party has adhered to the reactionary ideology that romanticizes the peasantry and has striven to address the economic interests and social concerns of farmers. During the 1980s and the 1990s, it has progressively fashioned an agricultural policy agenda combining tax incentives, economic protectionism and welfare.

This new programmatic mix has enhanced the party's appeal to voters in the rural world. Over the years, the FN has expanded its support further from its original urban bastions. While underrepresented in the FN electorate during the 1980s and the 1990s, farmers have become a more solid base for the radical right in France since the early 2000s. On the supply side, the FN's electoral success in the agricultural sector has been concomitant with a significant increase in salience of farming issues in the party's manifestos. On the demand side, the rise of the radical right among farmers has reflected growing dissatisfaction with the agricultural status quo represented both by the EU's CAP and mainstream farming policies.

More recently, rural themes were connected with socio-economic issues. In 2012, the FN embraced a more leftist and interventionist economic agenda. Its new politics of the rural appealed to the 'forgotten rural France'. Its broad catch-allist populist strategy reached out to a more diverse rural 
constituency comprising not only farmers but also voters in low income households clustered in periurban areas.

Today, the FN is more rural and working-class than it has ever been. While both the agricultural and industrial sectors continue to decline, the natural shrinking of its base of support could limit the FN's electoral progression. According to Kitschelt (1995:23), radical right parties relying too heavily on the narrow confines of the working class are bound to fail electorally. Moreover, working class voters in France are more prone to abstain and make therefore a more volatile support. The future of the French radical right will depend therefore on its ability to tackle larger shares of the middle-class vote to establish a broader electoral coalition. Widespread economic insecurity and profound political discontent may further destabilize and polarize middle-class voters, paving the way to future electoral victories by the FN.

\section{References}

Betz, Hans-Georg (1994) Radical Right-Wing Populism in Western Europe, Basingstoke: Macmillan.

Bihr, Alain (1998) Le spectre de l'extrême droite. Les Français dans le miroir du Front National. Paris: Editions de l'Atelier

Boswell, Laird (1998) Rural Communism in France, 1920-1939. Cornell University Press

Boussard, Isabel, and Jean Chiche. 1992. "Les Élections Présidentielles et Législatives de 1988, Européennes de 1989. Analyse Écologique Globale." In Les Agriculteurs Français Aux Urnes, edited by Bertrand Hervieu. Paris: L'Harmattan.

Boy, Daniel, and Nonna Mayer. 1997. "Que Reste-T-II Des Variables Lourdes?" In L'électeur a Ses Raisons, edited by Daniel Boy and Nonna Mayer, 101-138. Paris: Presses de Sciences Po.

Bussi, Michel (2003) Le vote Saint-Josse : la protestation en campagne, in Le vote de tous les refus, Perrineau, Pascal and Colette Ysmal, eds, Paris: Presses de la F.N.S.P., pp.311-338

Bussi, Michel, Céline Colange, and Jean Rivière. 2011. "Distance(s) À La Ville et Comportements Électoraux. Quelques Éclairages Quantitatifs Lors Des Derniers Scrutins Présidentiels." In Données Urbaines 6, edited by Marie-Flore Mattéi and Denise Pumain. Paris: Anthropos.

Canovan, Margaret (1981), Populism, London-New York, Harcourt Brace Jovanovich

Cartier, Marie, Isabelle Coutant, Olivier Masclet, and Yasmine Siblot. 2008. La France des "petitsmoyens": enquête sur la banlieue pavillonnaire. Textes à l'appui. Série Enquêtes de terrain. Paris: La Découverte.

Cautrès, Bruno, and Nonna Mayer. 2004. "Les métamorphoses du «vote de classe»." In Le nouveau désordre électoral. Les leçons du 21 avril 2002, edited by Bruno Cautrès and Nonna Mayer, 143-159. Paris: Presses de Sciences Po.

Chalard, Laurent. 2006. "Le Vote D'extrême Droite Dans L'aire Métropolitaine Marseillaise." EspacesTemps.net (November 10). http://espacestemps.net/document2101.html. 
Davezies, Laurent. 2008. La République et Ses Territoires: La Circulation Invisible Des Richesses. La République Des Idées. Paris: Seuil.

Fourquet, Jérôme. 2008. "L'érosion électorale du lepénisme." In Le vote de rupture. Les élections présidentielles et législatives d'avril-juin 2007, edited by Pascal Perrineau, 213-234. Chroniques électorales. Paris: Presses de Sciences Po.

Fourquet, Jérôme. 2012. Le Sens Des Cartes. Analyse Sur La Géographie Des Votes À La Présidentielle. Les Essais. Paris: Fondation Jean-Jaurès.

Girard, Violaine. 2013. "Sur la politisation des classes populaires périurbaines." Politix n 101 (1) (June 4): 183-215. doi:10.3917/pox.101.0183.

Goguel, François (1981) Chroniques électorales: les scrutins politiques en France de 1945 à nos jours. 1. La Quatrième République. Paris: Presses de la Fondation nationale des sciences politiques.

Gombin, Joël, and Jean Rivière. 2013. "Éléments Quantitatifs Sur La Dimension Spatiale Des Effets Électoraux Des Inégalités Sociales Dans Les Mondes Périurbains Français (2007-2012)." In Nantes. http://halshs.archives-ouvertes.fr/halshs-00859598.

Gombin, Joël, and Pierre Mayance. 2010. "Tous Conservateurs ? Analyse Écologique Du Vote de La Population Agricole Lors de L'élection Présidentielle de 2007." In Les Mondes Agricoles En Politique, edited by Nonna Mayer, Pierre Muller, Bertrand Hervieu, Jacques Rémy, and François Purseigle, 193216. Paris: Presses de Sciences Po.

Gombin, Joël. 2013a. "The Front National Vote and Its Sectorial Support." In Institut d'études politiques de Bordeaux. http://halshs.archives-ouvertes.fr/halshs-00861115.

Gombin, Joël. 2013b. "«Nouveau» FN, Vieille Carte Électorale? Les Territoires Du Vote Pour Le Front National de 1995 À 2012." In Section Thématique 27, "Un Nouveau Front National?", 12e Congrès de I'AFSP. Institut d'études politiques de Paris, 2013. http://halshs.archives-ouvertes.fr/halshs-00849332.

Guilluy, Christophe. 2010. Fractures Françaises. François Bourin Editeur.

Guilluy, Christophe. 2011. "Les Métropoles et La France Périphérique." Le Débat 166 (4): 42-52. doi:10.3917/deba.166.0042.

Hervieu, Bertrand, and François Purseigle. 2013. Sociologie des mondes agricoles. Paris: Armand Colin.

Ignazi, Piero (2003), Extreme Right Parties in Western Europe, Oxford: Oxford University Press

Ivaldi, Gilles (2012), « Permanences et évolutions de l'idéologie frontiste » in Pascal Delwit (ed.), Le Front national. Mutations de l'extrême droite française, Bruxelles: Editions de l'Université de Bruxelles, pp.95-112

Ivaldi, Gilles (2013) "Successful Welfare-Chauvinism? The transformation of the Front National's economic programme (1984-2012)", Paper delivered to the panel on "European populism in times of crisis" $20^{\text {th }}$ International Conference of Europeanists, Council for European Studies, Amsterdam, 25-27 June 
Kitschelt, Herbert, in collaboration with Anthony J. McGann (1995) Radical Right in Western Europe. A Comparative Analysis. Ann Arbor, MI: University of Michigan Press

Lévy, Jacques. 2003. "Vote et Gradient D'urbanité. L'autre Surprise Du 21 Avril." EspacesTemps.net. http://espacestemps.net/document432.html.

Lévy, Jacques. 2007. "Regarder, Voir. Un Discours Informé Par La Cartographie." Les Annales de La Recherche Urbaine (102): 131-140.

Lévy, Jacques. 2013. "Liens Faibles, Choix Forts: Les Urbains et L'urbanité." La Vie Des Idées (May 29). http://www.laviedesidees.fr/Liens-faibles-choix-forts-les.html.

Mayer, Nonna (1992) "Le vote des agriculteurs en 1988. Facteurs individuels, facteurs contextuels." In Les agriculteurs français aux urnes, edited by Bertrand Hervieu, 47-65. Alternatives rurales. Paris: L'Harmattan.

Mayer, Nonna (1995) "Les choix politiques ces agriculteurs." Cahiers Du CEVIPOF (12) (March): 27-38.

Mayer, Nonna (2002) Ces Français qui votent FN, Paris: Flammarion

Mayer, Nonna (2007) "Comment Nicolas Sarkozy a rétréci l'électorat Le Pen." Revue française de science politique Vol. 57 (3) (August 28): 429-445

Mayer, Nonna (2013) From Jean-Marie to Marine Le Pen: electoral change on the Far Right, Parliamentary Affairs, 66(1): 160-78.

Mayer, Nonna, and Pascal Perrineau. 1996. Le Front national à découvert. Paris: Presses de La Fondation Nationale Des Sciences Politiques.

Mischi, Julian and Michel Streith (2004) L'implantation du PCF. Bastions ruraux, bastions urbains, Études rurales, 171-172: 29-34.

Mudde, Cas (2007) Populist Radical Right Parties in Europe, Cambridge: Cambridge University Press

Ory, Pascal (1975) "Le dorgérisme. Institution et discours d'une colère paysanne (1929-1939)." Revue d'histoire moderne et contemporaine 22 (2): 168-190.

Paxton, Robert O (1997) French Peasant Fascism: Henry Dorgères's Greenshirts and the Crises of French Agriculture, 1929-1939. New York: Oxford University Press.

Perrineau, Pascal (1998) Le symptôme Le Pen : radiographie des électeurs du Front national, Paris: Fayard

Perrineau, Pascal (2002) Jean-Marie Le Pen, le grand retour électoral, Futuribles, juin

Perrineau, Pascal. 1996. "Les Étapes D'une Implantation Électorale (1972-1988)." In Le Front National À Découvert, edited by Nonna Mayer and Pascal Perrineau, 37-62. Références. Paris: Presses de Sciences Po. 
Rémy, Pierre (1972) "Le gaullisme et les paysans." In L'univers politique des paysans dans la France contemporaine, edited by Yves Tavernier, Michel Gervais, and Michel Servolin, 255-272. Cahiers de la Fondation nationale des sciences politiques. Paris: Armand Colin.

Rivière, Jean. 2008. "Le Vote Pavillonnaire Existe-t-II? Comportements Électoraux et Positions Sociales Locales Dans Une Commune Rurale En Cours de Périurbanisation." Politix (83): 23-48.

Rivière, Jean. 2009. "Le Pavillon et L'isoloir. Géographie Sociale et Électorale Des Espaces Périurbains Français (1968-2008). A Travers Les Cas de Trois Aires Urbaines Moyennes (Caen, Metz et Perpignan)". Doctorat, Caen: Université de Caen Basse Normandie.

Woods, Michael (2003) Deconstructing rural protest: the emergence of a new social movement, Journal of Rural Studies 19: 309-325

\section{Tables and Figures}

Table 1. FN national electoral results since 1973

\begin{tabular}{|c|c|c|c|c|c|}
\hline Year & Election & $\%$ valid & Year & Election & $\%$ valid \\
\hline 1973 & Legislative & 0.5 & 1997 & Legislative & 14.9 \\
\hline 1974 & Presidential & 0.7 & 1998 & Regional & 15.0 \\
\hline 1978 & Legislative & 0.8 & 1999 & European & 5.7 \\
\hline 1979 & European & 1.3 & 2002 & Presidential & 16.9 \\
\hline 1981 & Presidential $^{(1)}$ & -- & 2002 & Presidential $^{(2)}$ & 17.8 \\
\hline 1981 & Legislative & 0.3 & 2002 & Legislative & 11.3 \\
\hline 1984 & European & 11.0 & 2004 & Regional & 14.7 \\
\hline 1986 & Legislative & 9.6 & 2004 & European & 9.8 \\
\hline 1986 & Regional & 9.6 & 2007 & Presidential & 10.4 \\
\hline 1988 & Presidential & 14.4 & 2007 & Legislative & 4.3 \\
\hline 1988 & Legislative & 9.7 & 2009 & European & 6.3 \\
\hline 1989 & European & 11.7 & 2010 & Regional & 11.4 \\
\hline 1992 & Regional & 13.7 & 2012 & Presidential & 17.9 \\
\hline 1993 & Legislative & 12.4 & 2012 & Legislative & 13.6 \\
\hline 1994 & European & 10.5 & & & \\
\hline 1995 & Presidential & 15.0 & & & \\
\hline
\end{tabular}

${ }^{(1)}$ The FN did not run in the 1981 presidential election; ${ }^{(2)}$ Second-round runoff; \% of valid vote cast

Figure 1. Change in the issue profile of the Right and the FN on agriculture and farming ${ }^{(1)}: 1986-$ 2012

SEE ATTACHED FILE in TIFF format

${ }^{(1)}$ As \% of quasi-sentences/paragraphs referring to specific policies in favour of agriculture and farmers in each legislative
manifesto; Right=unweighted average of Gaullists (RPR, UMP) and Centre-Right (UDF, MODEM)
Source: Comparative Manifesto Project (CMP) Database for France, authors' data for 2012 based on presidential manifestos 
Figure 2. Predicted FN presidential vote as a difference to the mean ${ }^{(1)}$ by share of farmers in the population: $1995-2012$

\section{SEE ATTACHED PDF}

(1) Predicted vote for the FN expressed as a difference from the overall mean on the time span. Scores were estimated from a multilevel growth model, fitted on aggregate data at the cantonal and departmental levels. The detailed specification of the model can be found in Gombin (2013b).

Sources: Ministère de l'Intérieur, Ministère de l'Éducation nationale, INSEE.

Figure 3. Estimated Marine Le Pen vote ${ }^{(1)}$ among farmers in the 2012 presidential election

\section{SEE ATTACHED PDF}

(1) Estimates are derived from a multilevel model fitted on aggregate data at the commune and département levels. Sources: Ministère de l'Intérieur, INSEE

Figure 4. Vote for the $\mathrm{FN}$ in presidential elections according to urban configurations ${ }^{(1)}$

\section{SEE ATTACHED PDF}

(1) The municipalities (communes) were classified using the 1999 "urban and rural area zoning" devised by INSEE. Sources: Ministère de l'Intérieur, INSEE 